CRTST, Centre for Research on Inequality,

Department of International Development, University of Oxford

\title{
Macro Adjustment Policies and Horizontal Inequalities
}

\author{
Arnim Langer and Frances Stewart \\ CRISE WORKING PAPER No. 50 \\ January 2008
}

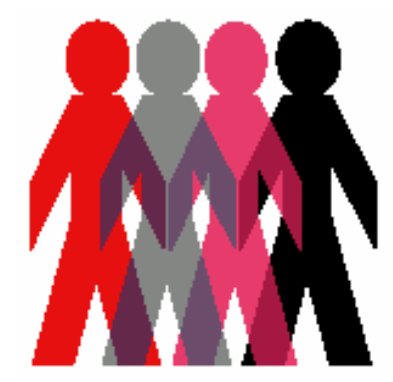




\title{
Macro Adjustment Policies and Horizontal Inequalities
}

\begin{abstract}
While there has been a considerable amount of analysis on the impact of structural adjustment policies on poverty and inequality among individuals (or what we define here as vertical inequality $-\mathrm{VI}$ ), there has been almost none into the impact of structural adjustment on inequality between culturally defined groups, or horizontal inequality $(\mathrm{HI})$. Although relatively neglected in economic analysis, socioeconomic HIs are important from a number of perspectives - they can have adverse effects on the wellbeing of members of the deprived groups, they can impede efficiency, they may make it very difficult to eradicate poverty, they lead to unfair and exclusionary societies, and they raise the risk of violent conflict. Hence it is important to analyse the impact of structural adjustment policies on Hls - which is the aim of this paper.
\end{abstract}

The authors

Arnim Langer is Research Officer in Economics and Politics at the Centre for Research on Inequality, Human Security and Ethnicity (CRISE), Department of International Development, University of Oxford.

Email: arnim.langer@geh.ox.ac.uk

Frances Stewart is Professor of Development Economics at the University of Oxford and Director of CRISE, Department of International Development, University of Oxford.

Email: frances.stewart@geh.ox.ac.uk 


\section{$\underline{\text { Table of Contents }}$}

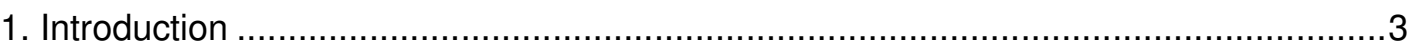

2. Defining group inequalities; why they are important..............................................

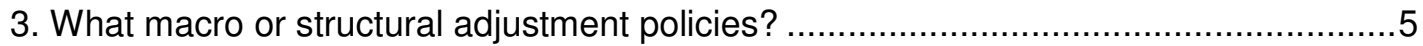

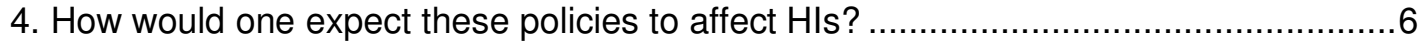

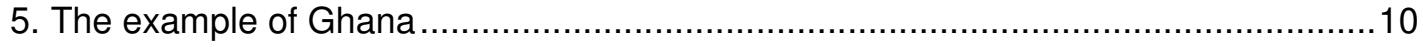

5.1 Ghana's horizontal inequalities and the adjustment experience ................... 10

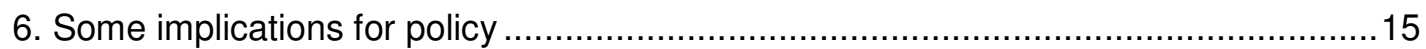

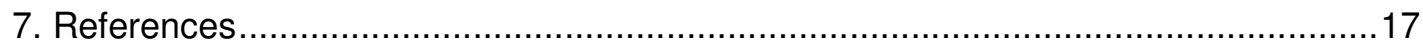

\section{List of Figures and Tables}

Figure 1: Thailand - Relative GDP per capita in three Malay-Muslim-dominated

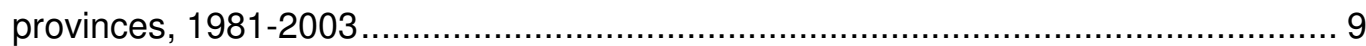

Table 1: Summary of expectations of how macro-policy changes are likely to affect

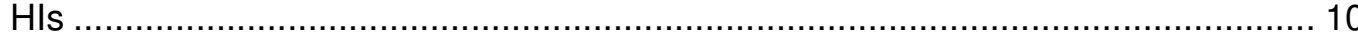

Table 2: Ghana's macroeconomic performance, 1983-1998 (\% unless otherwise

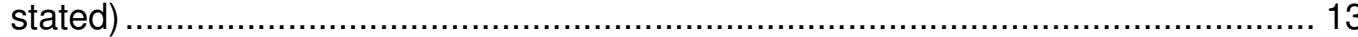

Table 3: Distributional effects of some adjustment policies on the north-south divide

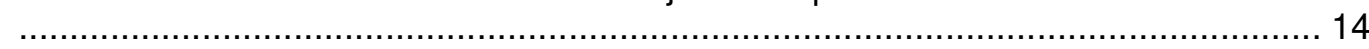

Table 4: Incidence of poverty by region (in \%) ................................................. 15 


\title{
Macro Adjustment Policies and Horizontal Inequalities
}

\author{
By Arnim Langer and Frances Stewart
}

\section{Introduction}

While there has been a considerable amount of analysis on the impact of structural adjustment policies on poverty and inequality among individuals (or what we define here as vertical inequality - VI) ${ }^{1}$, there has been almost none on the impact of structural adjustment on inequality between culturally defined groups, or horizontal inequality $(\mathrm{HI})$. This paper investigates this issue.

HIs encompass multiple dimensions - political, social, economic and cultural status. All of these dimensions are important in terms of causing grievances, and mobilising people politically, sometimes leading to violent conflict. In this paper, however, we are concerned only with the socioeconomic dimension: that is, group inequalities in a vector of social inputs and human development achievements (such as access to education and health services, nutrition rates, literacy rates, life expectancy, infant mortality rates, and so on), and a vector of economic inputs and achievements, including access to a variety of assets, to employment of different types, and the consequent consumption and incomes.

Although relatively neglected in economic analysis, socioeconomic HIs are important from a number of perspectives - they can have adverse effects on the wellbeing of members of the deprived groups, they can impede efficiency, they may make it very difficult to eradicate poverty, they lead to unfair and exclusionary societies, and they raise the risk of violent conflict (Stewart, 2001).

Because of their clear political significance, in some heterogeneous societies (notably Malaysia, South Africa, Northern Ireland, Fiji) a variety of policies have been adopted to attempt to reduce Hls - for example, through affirmative action of various kinds (giving preferences to particular groups in employment, education and asset ownership), through the careful allocation of public expenditure and through the use of the legal system to eliminate discrimination. While these policies can achieve much, their impact can be severely reduced or even offset if macro-economic policies simultaneously work to increase Hls. Conversely, if macro-policies support a reduction of Hls, the effectiveness of the other policies will be greatly increased (and HIs may fall even without any explicit affirmative action).

Hence it is important to analyse the impact of structural adjustment policies on Hls which is the aim of this paper. The paper is organised as follows: the next section further discusses the meaning of Hls and why they are important. Section 3 identifies the macro-policies to be analysed. Section 4 analyses how one might expect these policies to affect HIs, while section 5 draws on empirical evidence. Section 6 concludes with some discussion of the type of analysis needed in designing macropolicies in heterogeneous societies, and policy prescriptions suggested by our analysis.

\footnotetext{
${ }^{1}$ See for example: Bourgignon, et al. (1992), Stewart (1995), Singh (2000), Agénor (2004).
} 


\section{Defining group inequalities; why they are important}

First, it is necessary to consider the type of groups under consideration. This paper is concerned with group distinctions that are widely recognised by people in a particular society as of social and political significance. In practice, important group distinctions often arise from differences in religion (for example, from differences between major religions, such as Muslims and Christians, and groupings within them, such as Shia and Sunni, Catholic and Protestant); in some societies ethnic distinctions are important (for example, Ewes and Akans in Ghana, Igbo, Hausa-Fulani and Yoruba in Nigeria); in some - such as India and Nepal - caste is the main basis of social distinction and discrimination; in some places, geographical distinctions are important (often accompanied by some ethnic or religious differences), such as in East Timor or Eritrea; and in others, what we call 'race' seems to be the significant differentiating group characteristic, such as in Malaysia or Brazil.

Socially significant group identities arise partly from individuals' own perceptions of membership of and identity with a particular group and partly from the perceptions of those outside the group about others. An important question - long debated by anthropologists ${ }^{2}$ - then is why and when some differences are perceived as being socially significant, and others are not, both by group members themselves and by others. Here we will not enter that debate, but note that group distinctions are formed and reformed historically; that leaders, educators and the media, among others, are important influences over how significant group distinctions evolve; that groups often have uncertain boundaries, and are fluid, with new groups emerging and old ones ceasing to be important. Yet despite the fact that boundaries evolve, at any one time group distinctions are an important factor in the way that people see themselves, and interact, and consequently are relevant to the wellbeing of individuals and the health of society. Moreover, as ideology has become less important as a source of identity and political mobilisation, ethnic and religious distinctions seem to have become more important, as indicated by the increasing proportion of violent conflicts that are presented and labelled as 'ethnic'.

While the determinants of group wellbeing and prospects go well beyond their social and economic situation and include political and cultural status dimensions, this paper is concerned only with socioeconomic aspects. There are multiple elements within the broad socioeconomic category which may be important to people, as noted in the introduction. Most of these elements are important in themselves and are also instrumental for achieving others. For example, education is wanted in itself (as an important basic human right) and also as a means to enhance incomes, and similarly access to land represents status and security and also generates incomes.

While certain socioeconomic outcomes are relevant across all societies - notably incomes, health, and nutrition - what is needed to achieve these outcomes can vary across societies, and therefore also the particular inequalities which are of most significance. For example, access to primary education may be an important source of inequality in very poor societies, but in more developed countries where there is universal primary education, access at higher educational levels is more important. Equally, access to and ownership of land is of huge importance where agriculture accounts for a considerable proportion of output and employment, but becomes less important as development proceeds, and access to housing and formal sector jobs becomes more important.

Hls matter because:

\footnotetext{
${ }^{2}$ See Banks (1996) and Ukiwo (2005) for that debate.
} 
- Unequal access to political, economic, and social resources and inequalities of cultural status can have a serious negative impact on the welfare of members of poorer groups who mind about their relative position and that of their group. This is illustrated by research in the U.S. showing that the psychological health of blacks in the US is adversely affected by the position of the group to which they belong (see, for example, Broman, 1997; Brown, et al., 1999). Including the position of the group as a factor determining individual welfare has been modelled theoretically by Akerlof and Kranton (2000).

- Severe horizontal inequalities may reduce the growth potential of society, because they mean that some people do not have access to education or jobs on the basis of their potential merit or efficiency but are discriminated against because of the group to which they belong. As deprived groups get improved access to education and jobs, the potential of the economy can be realised more fully. This was exemplified by the rapid growth experienced in Malaysia as policies enabled the majority Malay population to participate in economic transformation (see, Faaland, et al., 2003).

- Horizontal inequalities can prove a major handicap to the elimination of poverty because it is difficult to reach members of deprived groups effectively with programmes of assistance. This is especially so because deprived groups face multiple disadvantages and discrimination and these need to be confronted together. This has been a serious problem, for example, in tackling poverty in the Andean countries (see, Hall and Patrinos, 2006).

- Finally, sharp group inequalities make violent group mobilisation and ethnic conflicts more likely, by providing powerful grievances which leaders can use to mobilise people, by calling on cultural markers (often common ethnicity or religion) and pointing to group exploitation. Evidence across countries has found a significant relationship between Hls and the onset of violent conflict (see, for example, Østby, 2006). Other statistical cross-country work supporting this relationship includes Gurr's successive studies of relative deprivation and conflict (see Gurr and Moore, 1997; Gurr, 1970; Gurr, 1993), and Barrows' investigation of sub-Saharan African countries in the 1960s (Barrows, 1976). Within country studies present a similar picture (see, for example, Mancini (2005) on Indonesia and Murshed and Gates (2005) on Nepal) showing that the location of conflict within the country is related to the extent of group inequality. Of course, not all countries with high Hls experience conflict - it is a matter of increased likelihood of greater incidence of conflict as Hls increase.

Hence the extent of socioeconomic Hls is an important issue in any heterogeneous society and should be a concern for policy, especially in economies which are vulnerable from a conflict perspective for other reasons. Research has shown that countries with low per capita incomes and those that have recently experienced conflict are particularly prone to conflict (Auvinen and Nafziger, 1999), so it is especially important to consider the impact of macro-policies on HIs in low-income and post-conflict economies.

\section{What macro or structural adjustment policies?}

Four types of policy make up International Monetary Fund (IMF)/World Bank adjustment and stabilisation policies:

i. (Dis)absorption policies.

ii. Switching policies

iii. Capital account liberalisation and financial reforms

iv. Other efficiency promoting policies 
We shall focus just on the first two. The effect of capital account liberalisation - which Ajit Singh ${ }^{3}$ has so powerfully analysed both for general implications and for VI, although not for $\mathrm{HI}$ - clearly has important potential implications for $\mathrm{HIs}$ although it has limited relevance for the poorest countries. This is an issue which we reserve for future analysis. The fourth category consists of a large range of policies, which mainly do not qualify as macro-policies.

Disabsorption policies are those policies that reduce total expenditure in the economy, releasing resources for exports and/or reducing imports and inflationary pressures. Policies include raising taxation and other sources of revenue, reducing public expenditure, and monetary restrictions (reduced money supply, raised interest rates) which lead to a cutback in private expenditure. Real devaluation of the exchange rate also has a disabsorption effect, by reducing real domestic incomes.

Switching policies are policies which aim to encourage resources to move into the tradable sector, encouraging resources to move into the export sector and into the production of import substitutes, hence improving the balance of trade. Policies include exchange rate depreciation and reduced taxes of exports. Reductions in tariffs and import quotas, which typically form part of the adjustment policy package, however, can offset the impact of devaluation in promoting import substitution. Generally, the combination of devaluation and tariff reforms reduces the overall disincentive to import and changes the relative prices of particular imports, the details varying across cases.

Such policies were highly visible in the 1980 s, with disabsorption policies dominating. For example from 1980-84, all 93 IMF agreements included limits on credit expansion, $92 \%$ restraints on public expenditure, $83 \%$ reduced public sector deficits, while just half the agreements involved exchange rate reforms and a similar proportion trade liberalisation (IMF, 1986). Since the early 2000s, poor countries' policy making has been dominated by Poverty Reduction Strategy Papers (PRSPs), while middle-income countries have done much to accumulate their own resources, or to borrow from the private sector, and have aimed to avoid the ministrations of the IMF. Nonetheless, despite these changes, the disabsorption and switching policies remain an essential aspect of policy making in poor countries as shown by analysis of the macro-aspects of the PRSPs (see, Stewart and Wang, 2005). Moreover, control over absorption has become an important policy tool of the middle-income countries in their efforts to avoid needing the assistance of the IFIs, and exchange rate depreciation an important tool to avoid a recurrence of financial crises like those in East Asia and Mexico in the 1990s.

\section{How would one expect these policies to affect HIs?}

The likely distributional impact of the two sets of policies depends on two factors: first, precisely how the policies are designed - for example whether taxes are raised or public expenditure reduced in the case of disabsorption policies; the balance of tax rises and expenditure reductions; and what type of tax and what type of expenditure are increased/reduced; and similarly the nature of the exchange rate and trade policy reforms in the case of switching policies. And secondly, how the different salient groups are positioned in the economy.

Suppose there are just two groups, a richer group, $\mathrm{R}$, and a poorer group, $\mathrm{P}$, and HIs are measured in summary by the ratio of average per capita incomes of the two, $\mathrm{y}^{\mathrm{r}}$

\footnotetext{
${ }^{3}$ See Singh (2007) for the latest of many powerful critiques of liberalisation policies.
} 
$/ y^{p}{ }^{4}$ The two groups will then differ on average as to their consumption as well as income levels, so if the additional taxation is progressive (bears more heavily on the rich), it will reduce incomes of $\mathrm{R}$ more than $\mathrm{P}$ and consequently reduce the $\mathrm{HI}$, but if it is regressive, the reverse will occur. The two groups are also likely to differ as to how they benefit from public expenditure. Social expenditure tends to be distributed progressively and the rest of public expenditure regressively, while the overall distributional impact of public expenditure varies across societies, but on balance seems to be mildly progressive (i.e. slightly favouring the poor) (Chu, et al., 2000; Cornia, 2004; Van de Walle, et al., 1995). Then public expenditure cuts that are disproportionately concentrated on the social sectors will hurt $P$ relatively to $R$, and conversely if they are concentrated on other sectors, while a 'neutral' across the board cut will tend to hurt $\mathrm{P}$ more than $\mathrm{R}$.

This assumes that the only way the two groups differ is with respect to income levels, but the groups are not defined by their incomes but by some cultural characteristics, which may affect the distributional impact. For example, some groups save more than others, so will be less affected by consumption taxes as against income taxes; some groups consume less alcohol, so will be less affected by alcohol tax rises; groups differ in the use they make of public services (for example some groups are more likely to attend school for cultural reasons), and thus will be differentially affected by different types of expenditure cuts. Groups are often concentrated in particular regions - for example Muslims in the North of Nigeria; indigenous people in the highlands of Peru. Consequently, any tax increases or expenditure cuts that are not regionally neutral will have implications for group distribution.

In general, a typical aspect of a society with severe Hls is that the distribution of the benefit of public expenditure is unequal across the groups, i.e. $p^{p}<p^{r}$, where $p^{p}$ represents public expenditure benefits per head of group $P$, and $p^{r}$ represents public expenditure benefits per head of group R. While 'neutral' decreases in expenditure (i.e. affecting everyone proportionately to their initial benefits) would leave HIs unchanged, such neutrality cannot be assumed as it is likely that group $R$ will control the budget and may ensure that the cuts do fall more than proportionately on $\mathrm{P}$.

We have so far considered the two groups as consumers of public goods, but they are also producers. As producers, $\mathrm{R}$ can, perhaps, be expected to suffer from cutbacks in public employment more than $\mathrm{P}$ but if the cutbacks consist in labourintensive infrastructural expenditure this might not be the case.

Hence a careful analysis of the characteristics of the different groups and of the design of tax increases or expenditure cuts is necessary to identify the impact on HIs from disabsorption policies. It is therefore difficult to make any a priori generalisations, though one can state, fairly confidently, that (a) tax increases are likely to be more beneficial for poor groups than expenditure reductions; (b) however, because an important aspect of HIs is distorted public expenditure against poorer groups, expenditure cuts may actually improve their relative position, assuming that the cuts are not also distorted; (c) progressive tax increases are more beneficial than regressive ones; (d) expenditure cuts focussed on social sectors are likely to worsen HIs relative to expenditure cuts that protect social expenditure; (e) cutbacks in public sector employment may hurt $\mathrm{R}$ more than $\mathrm{P}$, but again where the cuts fall is critical.

\footnotetext{
${ }^{4}$ This is a simplified way of measuring HIs; we might use a measure that also incorporates some weighting for different parts of the income distribution of the two groups (see, Mancini, et al., 2008).
} 
Turning to switching policies, we again need to differentiate between the impact on groups as producers and on groups as consumers. The outcome on groups as producers depends largely on group specialisation in production. This is often quite marked as a result of colonial policy and its aftermath and geographic disadvantage. Thus colonial policy involved a sharp racial division of labour in Malaysia, with the Chinese the trading and entrepreneurial class, the Indians imported to work on plantations and the Malays subsistence farmers (Brown, 1997). Similarly, in many African economies, particular groups were picked out by colonialists for privileged education and for specialisation in cash crops - often a specialisation associated with advantages of geography, so that Southern groups were favoured for education and cash crops in West and East African countries (see, for example, Songsore (2003) for Ghana and Ghai and Court (1974) for Kenya). In other economies, settlers took all the best land and the top jobs in the civil services, and where settlers remained in the country, post-independence, as in Latin America and South and Central Africa, this became a major source of Hls (Figueroa, et al., 1996). In some economies colonial powers imported indentured or slave labour to work on plantations (for example, Brazil and Guyana) and build roads or railways (for example, Kenya). Consequently, for these (and other) reasons, $\mathrm{R}$ and $\mathrm{P}$ tend to be differently inserted into the economy.

Switching policies favour some sectors (tradables) and hurt others (non-tradables). Hence their impact on Hls depends on whether the ethnic division of labour follows this tradable/non-tradable distinction. For some economies it is clear that there is such an overlap, with $\mathrm{P}$ being more specialised in non-tradables (subsistence), and $\mathrm{R}$ more specialised in tradables. This broadly seems to be the case with respect to cash crops in many African economies. Below we exemplify this in more depth in the case of Ghana. But Ghana is just one example which typifies a swathe of countries across Africa. Elsewhere the impact is somewhat different. In economies with plantations and very poorly paid plantation labour, these workers (typically being members of a particular group) are often the poorest, with incomes below the peasant food producers; for example, the Indian plantation workers in Malaysia or Guyana or the Afro-Brazilians in Brazil. For these economies, switching policies may favour plantations, and hurt the somewhat richer peasant farmers. However, these gains are not necessarily passed on to the workers; they may go largely to the plantation owners who belong to the R group. A third type of economy is one where there are incipient labour-intensive industries and switching favours this sector. The $\mathrm{HI}$ implications depend on which group the new labourers come from. In Malaysia, the poorest group, the bumiputera, supplied much of this new labour - assisted by supportive education and employment policies (see, Faaland, et al., 2003).

A fourth type involves comparative advantage lying with skill- or capital-intensive products (like software services and call centres in India, or airplanes in Brazil). In these cases, switching policies will favour producers of these products, who, generally, are likely to be in group R. However, in the case of skill-intensive products, this also depends on complementary education and training policies that might be designed to improve the capacities and job access of $P$.

There can also be regional and $\mathrm{HI}$ consequences from rapid industrialisation, where one region of a country benefits much more than others, creating regional and, quite often, ethnic Hls. China is an obvious example. Thailand is another. Although Thailand has seen rapid growth and labour-intensive industrialisation over the past 25 years, the three mainly Malay-Muslim provinces have remained at levels well below the national average (see, Figure 1). While two of three Muslim-Malay provinces - Yala and Narathiwat - experienced a significant decline in their relative economic standing, each falling by around $20 \%$ of relative GDP per capita, the third 
one, Pattani, did better, but remained nonetheless significantly below the national average (Brown, 2008).

Figure 1: Thailand - Relative GDP per capita in three Malay-Muslim-dominated provinces, 1981-2003

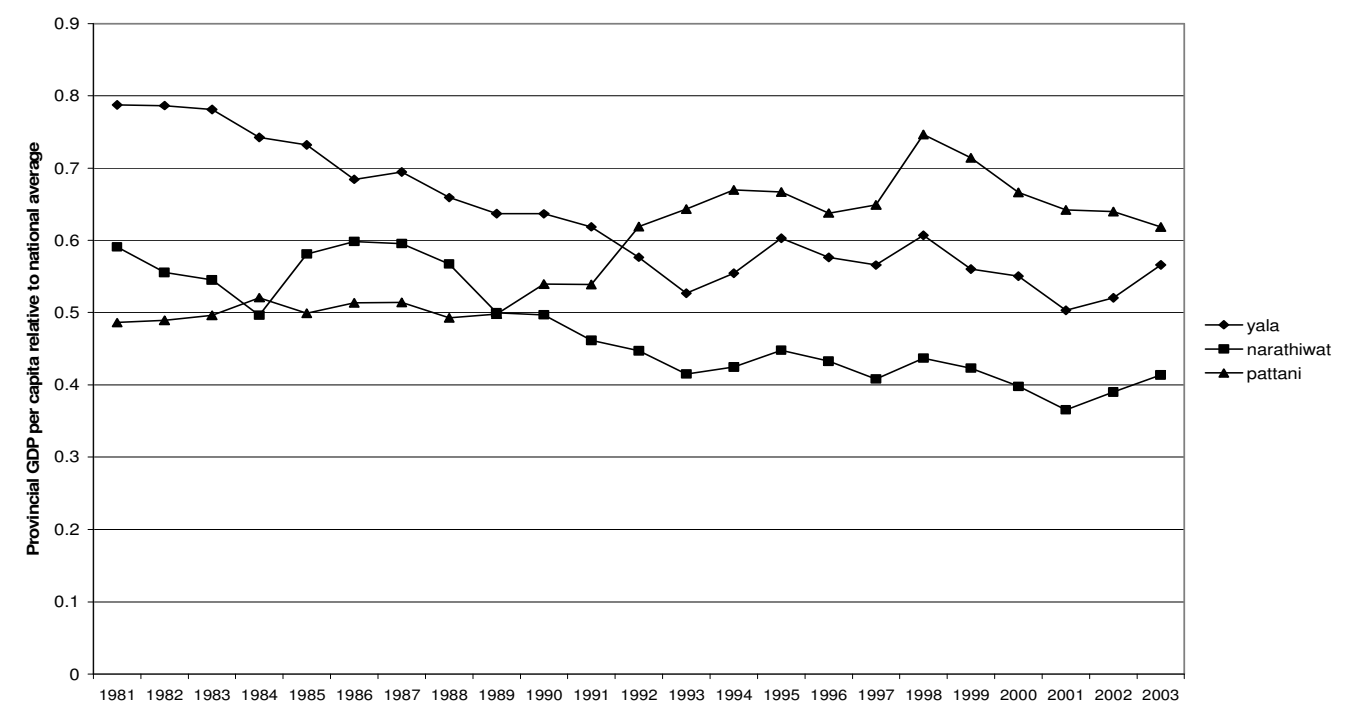

Source: Brown (2008).

A fifth type of economy is one that specialises on minerals - for example oil. In such economies, the revenue from the resources tends to be disproportionately received by $R$, either directly or indirectly via government redistributionary policies. Where this is the case, any across-the-board depreciation would increase such revenue and tend to worsen HIs. But multiple exchange rates might prevent this effect and could be designed to help particular groups. A further complication is that non-tradables extend beyond subsistence agriculture to import-substituting activity behind heavy protection. Often it is $R$ rather than $P$ that is concentrated in this sector. If this protection is withdrawn as part of the switching policies, then undoubtedly some $R$ will lose. This may apply in any of the four types of economy differentiated above.

Turning to the impact of exchange rate changes and tariff reforms on groups as consumers, the outcome depends on the design of the policies. It appears that tariff and quota reductions tend to favour richer groups, as import tariffs often bear most heavily on luxury consumption, but such reductions may not be universal (although they normally are) but could be retained on the products consumed by the rich, thereby altering the distributional impact.

It is possible to generalise a bit more about the likely impact of switching policies on groups as producers than of disabsorption policies on Hls. First, in economies where there is crop specialisation by group and crops are the main tradables, switching policies are likely to increase HIs; secondly, in plantation economies, they may somewhat improve them; thirdly, in economies in which the policies promote labourintensive industrialisation, those with basic education are likely to gain (see, Wood and Ridao-Cano, 1996), which in the normal case would tend to favour the richer and better educated group(s), although this can be offset by education and employment policies that favour the poorer groups; fourthly, regionally, effective switching policies that promote rapid industrialisation are likely to lead to imbalances and accentuate or create regional Hls; fifthly, where the policies dismantle the protection of privileged import-substitution, it is possible that they improve Hls. Finally, like disabsorption 
policies, (but to a lesser extent), switching policies can be designed to help or hurt particular groups.

Table 1: Summary of expectations of how macro-policy changes are likely to affect Hls

\begin{tabular}{|l|l|l|l|l|}
\hline $\begin{array}{l}\text { Type of exports of } \\
\text { economy }\end{array}$ & $\begin{array}{l}\text { Primary product } \\
\text { agricultural } \\
\text { products }\end{array}$ & $\begin{array}{l}\text { Labour-intensive } \\
\text { industrial } \\
\text { products }\end{array}$ & $\begin{array}{l}\text { Capital- or skill- } \\
\text { intensive } \\
\text { industrial } \\
\text { products }\end{array}$ & $\begin{array}{l}\text { Minerals (for } \\
\text { example oil) }\end{array}$ \\
\hline $\begin{array}{l}\text { Switching policies } \\
\text { Worsen Hls }\end{array}$ & $\begin{array}{l}\text { Depends on } \\
\text { labour force skills, } \\
\text { complementary } \\
\text { wolicies; may } \\
\text { Hls }\end{array}$ & $\begin{array}{l}\text { Probably worsen } \\
\text { Hls }\end{array}$ & Worsen HIs \\
\hline $\begin{array}{l}\text { Reduced import- } \\
\text { substituting } \\
\text { protection }\end{array}$ & Improve Hls & & \\
\hline $\begin{array}{l}\text { Tax rises } \\
\text { Expenditure cuts }\end{array}$ & Depends on design & \\
\hline
\end{tabular}

\section{The example of Ghana}

In order to illustrate the impact of adjustment policies on group or horizontal inequalities, in this section we analyse the adjustment experiences of Ghana, focussing on the evolution of the main socioeconomic cleavage. In the Ghanaian case, we therefore analyse how the adjustment polices affected the socioeconomic north-south divide.

\subsection{Ghana's horizontal inequalities and the adjustment experience}

Like several other West African countries (for example, Côte d'Ivoire, Togo, Benin and Nigeria), the sharpest socioeconomic or developmental divide in Ghana is between the northern and southern regions, which overlaps closely with ethnic differences and is also associated with religious differences. This developmental North-South divide arises from a combination of circumstances and policies: 1) the geographical concentration of most agricultural activities/resources, particularly tree crops such as cocoa, as well as natural resources, notably minerals and forest resources, in the Southern regions; 2) the British colonial policy of investing more heavily in those regions where exploitable resources, such as gold, diamonds, timber, and cocoa, were available or readily produced and cheapest to export; and 3) post-colonial development strategies and investment patterns (see, among others, Bening (1975); Roe and Schneider (1992); Songsore (2003)).

At the time of gaining independence from Britain in 1957, Ghana had one of the most successful economies in Africa, with an average annual real growth rate of well over 
$5 \%$, substantial foreign reserves and a strong civil service (Mensah, et al., 2006). Ghana's successful economic record in the 1950s was based on an open economy with the private sector as the main source of growth (particularly small-scale cocoa farming). But from 1957, Ghana's first prime minister (and later president), Kwame Nkrumah, changed this to a state-led modernisation strategy based on importsubstituting industrialisation. Despite the increasing importance of the public sector, the main source of funding for Ghana's state-led industrialisation continued to come from the cocoa sector, which provided about $70 \%$ of Ghana's export earnings (Dordunoo and Nyanteng, 1997). Although some liberalisation efforts were initiated following Nkrumah's removal from power in February 1966, with the ascendancy to power of Colonel Ignatius Kutu Acheampong in 1972, Nkrumah's policies of statism and controls again became the dominant economic strategy.

This state-led approach had disastrous consequences for Ghana's economy, particularly as a result of reduced production of cocoa (partly due to adverse prices) and worsening international terms of trade, and a large external debt so that Ghana was unable to pay for the imports needed to run the industrial sector to capacity. Besides the economic strategy adopted, several exogenous factors were also responsible for the economic crisis, most notably the persistently unfavourable terms of trade for Ghana's main export products, severe droughts in 1978/79 and 1982/83, the repatriation of one million Ghanaians from Nigeria in 1983, and the high international interest rates sparked by the global economic crisis at the end of the 1970 s and the subsequent switch to monetarist policies in the advanced countries (Mensah, et al., 2006).

Against the backdrop of the economic malaise of the 1970s, Flight-Lieutenant Jerry Rawlings, who took power in a coup d'état in December 1981, established a military regime, known as the Provisional National Defence Council (PDNC). Although the PNDC regime initially responded to the prevailing economic problems in much the same way as previous governments had, in 1983 it reversed its economic course dramatically and started to implement an extensive economic reform programme locally known as the Economic Reform Programme (ERP) - with the support of the IMF and the World Bank (Herbst, 1993). Ghana's adjustment policies evolved through four phases: 1) ERP I - the period of economic stabilisation and recovery (1983-1986); 2) ERP II - the period of structural adjustment and growth (1987-1992); 3) ERP III - the period of accelerated growth (1993-2000); and 4) PRSP - the phase from 2001 to date. ${ }^{5}$ In what follows, we focus on the first three phases of Ghana's adjustment process.

ERP I (1983-1986) consisted of 'a stabilisation package designed to reduce inflation and achieve external equilibrium', and 'a programme to promote economic growth and export recovery through a realignment of incentives toward productive activity and the rehabilitation of economic and social infrastructure' (Hutchful, 2002, p. 56). A major component of the programme was the devaluation of Ghana's currency, the cedi, which changed from 2.75 cedis to $\$ 1$ in 1983 to 160 cedis to $\$ 1$ in 1986 (Leite, et al., 2000). The government also adjusted prices for other goods and services, including the cocoa producer price, retail petroleum prices and utility tariffs. For instance, the producer price of cocoa was increased to 86,000 cedis per tonne for the $1986 / 87$ crop year, which was a $50 \%$ increase relative to $1985 / 86$ and a quadrupling relative to 1983/84 (Roe and Schneider, 1992).

\footnotetext{
${ }^{5}$ This overview draws on Hutchful (2002) and Dordunoo and Nyanteng (1997) who both identify three phases in the evolution of Ghana's adjustment policies (although with somewhat different time periods); we have added the fourth one (i.e. the PRSP-phase).
} 
In the monetary and fiscal sphere, policies included the introduction of 'strict credit ceilings, increases in interest rates with the objective of reaching positive interest rates, reform of the tax structure to broaden the tax base and at the same time reduce the tax burden on corporations and the cocoa sector, and other measures to increase revenue, shrink the budget deficit (through retrenchment, elimination of subsidies, higher fees for government services, etc.) and reduce the reliance on the banking system' (Hutchful, 2002, p. 56). The government also launched an Export Sector Rehabilitation Programme 'designed to rehabilitate the export sectors by relieving supply and input bottlenecks, improving producer incentives, and reforming the State Cocoa Marketing Board (Cocobod)' (Ibid). In the mining sector, new legislation boosted incentives for (foreign) mining corporations, among other things, by reducing mining royalties, granting allowances on capitalisation expenditure for field reconnaissance and prospecting, and exempting mining sector machinery from import duties (Mensah, et al., 2006).

ERP II (1987-1992) inaugurated the adjustment phase and was intended to deepen ongoing reforms (Hutchful, 2002). During this phase, comprehensive reforms were directed towards Ghana's cocoa sector. In particular, in 1988, the government, with support from the World Bank, launched the Cocoa Rehabilitation Programme (CRP). CRP's two main objectives were to improve incentives for cocoa farmers by further raising the cocoa producer price and to lower the costs of the State Cocoa Marketing Board (Dordunoo and Nyanteng, 1997). Nearly 12,000 of the staff of the State Cocoa Marketing Board were made redundant in 1987 (Leite, et al., 2000, p. 26). Moreover, as part of the CRP, 'efforts were also made to improve the living conditions of farmers with rural development projects in feeder roads, healthcare and marketing facilities' (Mensah, et al., 2006, p. 111). Other reforms that were launched under ERP II included the introduction of a new Banking Law and new regulations for savings and loans companies; the establishment of the Ghana Stock Exchange Company in November 1990; and the adoption of a new Investment Code (Hutchful, 2002).

Under pressure from concerned citizens and international observers such as Oxfam and UNICEF, the government introduced the Programme of Actions to Mitigate the Social Costs of Adjustment (PAMSCAD) in 1987/88 in order to mitigate the adverse socioeconomic impact of the structural adjustment programmes on certain vulnerable groups in society (Mensah, et al., 2006). PAMSCAD was targeted at four vulnerable groups: 'first, small farmers and hired labour; second, poor households with limited access to basic social services such as health, education, water, etc.; third, the unemployed and those with meagre earnings, especially urban youth; and finally, households in the northern regions' (Hutchful, 2002, p. 117). As part of PAMSCAD, five types of projects (i.e. community initiative projects; employment generation projects; redeployment projects; projects aimed at providing basic needs and services, including water, sanitation, health, nutrition and shelter; and, projects aimed at improving educational infrastructure) were undertaken to improve the socioeconomic situation of the four target groups (lbid).

Under ERP III (1993-2000) growth acceleration became the main objective. 'The Accelerated Growth Strategy (AGS), published in 1993 emphasized sustainable development and poverty-alleviation through private sector development' (Hutchful, 2002, p. 57). In addition, the programme 'stressed the strengthening of inter-sectoral linkages (in particular through agro-industry), poverty reduction through labourintensive and high-productivity activities, enhanced access of the poor to social services, further progress in human resource development (particularly primary education and health), capacity building and public-sector management, and privatesector development' (Ibid). 
As shown in Table 2, Ghana's economic performance recovered after 1983, and a period of sustained growth followed. Other macroeconomic indicators also improved significantly, although there were some serious fiscal slippages in the run-up to the elections of 1992 and 1996 (Leite, et al., 2000). For example, before the 1996 election the mechanism for automatically adjusting retail petroleum prices for changes in the price of imported oil and the exchange rate was suspended, which caused a substantial shortfall in petroleum tax collections (lbid). While overall GDP growth of $4-5 \%$ was maintained in the 1990 s, 'both domestic and export production demonstrated significant fluctuations' (Hutchful, 2002, p. 66).

Table 2: Ghana's macroeconomic performance, 1983-1998 (\% unless otherwise stated)

\begin{tabular}{l|llll}
\hline & Real GDP growth & $\begin{array}{l}\text { Real GDP } \\
\text { per capita growth }\end{array}$ & $\begin{array}{l}\text { Export of cocoa } \\
\text { Inflation (CPI) }\end{array}$ & $\begin{array}{l}\text { (FAO) (metric } \\
\text { tons) }\end{array}$ \\
\hline 1982 & -6.9 & -9.7 & 22.3 & 260,130 \\
1983 & -4.6 & -7.7 & 123.8 & 166,390 \\
1984 & 8.6 & 4.9 & 39.7 & 162,070 \\
1985 & 5.1 & 1.3 & 10.3 & 187,790 \\
1986 & 5.2 & 1.6 & 24.6 & 211,420 \\
1987 & 4.8 & 1.3 & 39.8 & 218,850 \\
1988 & 5.6 & 2.2 & 31.4 & 223,260 \\
1989 & 5.1 & 1.8 & 25.2 & 265,810 \\
1990 & 3.3 & 0.2 & 37.3 & 269,730 \\
1991 & 5.3 & 2.2 & 18.1 & 265,200 \\
1992 & 3.9 & 1.0 & 10.0 & 243,100 \\
1993 & 5.0 & 2.1 & 25.0 & 278,380 \\
1994 & 3.3 & 0.6 & 24.9 & 252,420 \\
1995 & 4.0 & 1.4 & 74.3 & 253,260 \\
1996 & 4.6 & 1.9 & 46.6 & 371,990 \\
1997 & 4.2 & 1.5 & 27.9 & 303,710 \\
1998 & 4.6 & 1.9 & 19.3 &.. \\
\hline
\end{tabular}

Source: World Bank Africa 2000 Database.

Although Ghana's structural adjustment process contributed to restoring economic growth and macroeconomic stability, different regions benefited in different degrees from the recovery. Table 3 shows how some important adjustment policies are likely to have affected the north-south divide. In line with the ERP's objective to restore economic growth by rehabilitating Ghana's export economy, most external funding went to the Greater Accra Region (where the capital is located) and the cocoa, timber and mineral industries in the Western, Eastern, Ashanti and Brong Ahafo Regions, all in the southern part of the country. Ghana's northern regions largely failed to benefit from the ERP's economic stimulus (Songsore, 2003).

However, the retrenchment policies which resulted in a large number of lay-offs among the staff of the Cocoa Board and other civil/public service institutions also predominantly affected the southern regions. Price changes as a result of subsidy cuts, fee increases and tax changes, changes in the exchange rate, import quotas, tariffs and other indirect taxation show a diverse picture. The impact of these price changes was generally smaller in the northern regions because fewer people there had access to these goods and services before the adjustment process was initiated. While the projects that were undertaken as part of PAMSCAD generally had a positive impact on the situation in both the northern and southern regions, due to a 
serious funding shortfall the overall impact was rather limited. Out of an overall pledge to commit $\$ 84$ million to support PAMSCAD by the international community donors in February 1988, by the end of July 1990, only about $\$ 15$ million in donor financing had been received (Leite, et al., 2000). Consequently, overall, the adjustment policies appeared to have benefited the northern regions considerably less than the southern regions.

Table 3: Distributional effects of some adjustment policies on the north-south divide

\begin{tabular}{l|ll}
\hline & Northern regions & Southern regions \\
\hline Export Sector Rehabilitation Programme & & \\
Cocoa Reform Programme (CRP) & & ++ \\
- Cocoa prices & & - \\
- Removal of subsidies on farm inputs & & + \\
- Rural development initiatives & & + \\
Mining sector rehabilitation & & + \\
Forestry sector rehabilitation & & \\
Employment retrenchment policies & & - \\
- State Cocoa Marketing Board & & - \\
- Other public/civil service & $(+) ?$ & \\
Price changes as a result of subsidy cuts and & & \\
tax changes: & $(+) ?$ & $+?$ \\
Food & $(-)$ & $+?$ \\
Manufactures & $(-)$ & - \\
Gasoline & $(-)$ & - \\
Tobacco & $(-)$ & - \\
Alcohol & $(-)$ & - \\
Education & $(+)$ & - \\
Hospital & & $(+)$ \\
PAMSCAD & & + \\
\hline
\end{tabular}

Source: Authors devised, based on approach of Roe and Schneider (1992, p. 140).

Note: 'The symbols in this table express the nature of the effects of adjustment as negative and positive. The symbols are doubled where the effects have been relatively strong; they are put within brackets where they have been relatively weak. Blanks indicate that there have been no or negligible effects' (Roe and Schneider, 1992, p. 140).

This assessment is confirmed by the regional evolution of poverty in the 1990s, shown in Table 4. While there was an overall decline in poverty (measured as the number of people living on less than 900,000 cedis) at the national level, this reduction in poverty was not evenly distributed. Indeed, while the Accra region and the rural forest regions (i.e. where most of the cocoa plantations and mining and timber industries are located) saw a sharp decline in poverty, in the northern or savannah regions, in contrast, the incidence of poverty increased in the 1990s, except in the rural savannah regions. Moreover, not only was the decline in poverty in the rural savannah regions very small, and consequently the incidence of poverty remained very high in northern rural areas at more than $70 \%$, but also extreme poverty (measured as the number of people living on less than 700,000 cedis) actually increased in the rural savannah regions. ${ }^{6}$ Therefore, according to this

\footnotetext{
${ }^{6}$ The poverty line is anchored on caloric requirements and is therefore a nutrition-based poverty line. 'It focuses on the expenditure needed to meet the nutritional requirements of household members and was set at $\$ 700,000$ per adult per year for the 1998/99 survey year.
} 
socioeconomic indicator, Ghana's north-south divide clearly deteriorated under this phase of structural adjustment.

Table 4: Incidence of poverty by region (in \%)

\begin{tabular}{|c|c|c|c|c|}
\hline \multirow[b]{2}{*}{ Survey and Region } & \multicolumn{2}{|c|}{ Poverty Line $=\$ 900,000$} & \multicolumn{2}{|c|}{ Poverty Line $=\$ 700,000$} \\
\hline & Incidence & $\begin{array}{l}\text { Share of total } \\
\text { poverty }\end{array}$ & Incidence & $\begin{array}{l}\text { Share of total } \\
\text { poverty }\end{array}$ \\
\hline \multicolumn{5}{|l|}{ GLSS3 (1991/92) } \\
\hline Accra & 22.4 & 3.6 & 11.6 & 2.7 \\
\hline Urban coastal & 28.3 & 4.8 & 14.9 & 3.6 \\
\hline Urban forest & 25.8 & 5.6 & 12.9 & 4.0 \\
\hline Urban savannah & 37.9 & 4.0 & 27.0 & 4.0 \\
\hline Rural coastal & 49.7 & 13.8 & 30.7 & 12.2 \\
\hline Rural forest & 60.8 & 35.4 & 45.1 & 37.4 \\
\hline Rural savannah & 72.1 & 32.8 & 55.9 & 36.2 \\
\hline All Ghana & 50.8 & 100.0 & 35.7 & 100.0 \\
\hline \multicolumn{5}{|l|}{ GLSS4 (1998/99) } \\
\hline Accra & 4.7 & 0.9 & 2.4 & 0.6 \\
\hline Urban coastal & 26.8 & 5.3 & 17.1 & 5.1 \\
\hline Urban forest & 24.8 & 5.9 & 15.1 & 5.2 \\
\hline Urban savannah & 42.2 & 4.4 & 29.7 & 4.5 \\
\hline Rural coastal & 46.3 & 16.1 & 30.1 & 15.1 \\
\hline Rural forest & 41.4 & 31.6 & 24.4 & 26.9 \\
\hline Rural savannah & 70.5 & 35.6 & 58.2 & 42.6 \\
\hline All Ghana & 42.6 & 100.0 & 29.4 & 100.0 \\
\hline
\end{tabular}

Source: Leite, et al. (2000, p. 10).

In general, Ghana's stabilisation and adjustment policies did not take horizontal inequalities into account explicitly, though the poverty reduction strategies followed from 2001 do emphasise the need to reduce regional disparities. As shown, the design of the policies on balance helped the already privileged regions and did little for the most deprived region - the north - thereby exacerbating this aspect of horizontal inequalities in Ghana. Compensatory policies, such as PAMSCAD, did something to offset the impact of the programmes, but they were on too small a scale to prevent a widening of HIs in Ghana.

\section{Some implications for policy}

First, as we have shown, macro policies can have a major impact on Hls, which may go either way. Cuts in public expenditure can offset policies intended to improve the position of deprived groups, while switching policies can reduce income-earning opportunities in such a way as to undermine other affirmative action. But conversely, it is possible that macro policies can involve expenditure increases which benefit deprived groups, and switching policies may offer income earning opportunities to such groups, while reductions in public sector employment and import protection can hurt richer groups particularly. However, on balance in the one case we explored in

Persons whose total expenditure falls below this level are considered extremely poor. An upper line was also established which incorporates both essential food and non-food needs and set at $\$ 900,000$ per adult per year' (Leite, et al., 2000, p. 9). 
this paper, Ghana, poverty actually rose among some deprived regions (and groups), at a time when growth was positive and poverty was falling nationally. It is therefore important to consider the impact on Hls in designing macro-policies.

Secondly, the design of policies can greatly affect their impact on HIs. With disabsorption policies in particular, they can be designed in such a way as to improve HIs - through the balance of tax increases to expenditure reductions, and through the design of tax increases and where the expenditure reductions fall. Where HIs are not an explicit consideration, the impact is likely to be harmful, simply because the budget tends to be under the control of the more privileged groups. A conscious and possibly politically difficult - policy is needed to ensure that the disabsorption policies do not worsen HIs (and preferably improve them). Design of policies is also relevant to switching policies. Differential exchange rates may be used to help particular groups. And dismantling of import protection can be designed in ways that hurt the richer groups most. Again this is generally not a consideration, and reduced tariffs often permit imports of luxury goods at low prices.

Thirdly, complementary policies can help to make the macro-policies contribute to reducing HIs. In particular, education and training of the poorer groups will enable them to exploit the opportunities offered by a more open trading regime. Similarly, anti-discriminatory employment policies will permit the poorer groups to participate in the gains from international trade. Moreover, compensatory policies can be introduced to offset some adverse effects. Again such complementary or compensatory policies do not normally form part of the adjustment policy packages. Indeed, in the promoting-efficiency part of the package, formal direct affirmative action comes under attack. 


\section{References}

Agénor, P.-R. 2004 'Macroeconomic Adjustment and the Poor: Analytical Issues and Cross-Country Evidence', Journal of Economic Surveys 18: 351-408.

Akerlof, G. A. and Kranton, R. E. 2000 'Economics and Identity', The Quarterly Journal of Economics $\operatorname{cxv}(3)$ : 715-753.

Auvinen, J. and Nafziger, E. W. 1999 'The sources of humanitarian emergencies', Journal of Conflict Resolution, 43: 267-90.

Banks, M. 1996 Ethnicity: anthropological constructions, London: Routledge.

Barrows, W. L. 1976 'Ethnic diversity and political instability in Black Africa. ' Comparative Political Studies 9(2): 139-170.

Bening, R. B. 1975 'Colonial Development Policy in Northern Ghana, 1989-1950', Bulletin of the Ghana Geographical Association 17.

Bourgignon, F., de Melo, J. and Morrison, C. 1992 'Poverty and income distribution during adjustment: issues and evidence from the OECD project', World Development: 1485-1508.

Broman, C. 1997 'Race-related factors and life satisfaction among African Americans', Journal of Black Psychology 23(1): 36-49.

Brown, G. K. 2008 'Horizontal inequalities and separatism in Southeast Asia: a comparative perspective ', in F. Stewart (ed) Horizontal Inequalities and Conflict: Understanding Group Violence in Multiethnic Societies, London: Palgrave.

Brown, I. 1997 Economic Change in South-East Asia, c.1830-1980., Kuala Lumpur: Oxford University Press.

Brown, T. N., Williams, D. R., Jackson, J. S., Neighbours, H., Sellers, S., Myriam, T. and Brown, K. 1999 'Being black and feeling blue: mental health consequences of racial discrimination', Race and Society 2(2): 117-131.

Brydon, L. and Legge, K. 1996 Adjusting Society: the World Bank, the IMF and Ghana, London and New York: I.B. Tauris Publishers.

Chu, K.-y., Davoodi, H. R., Gupta, S. and World Institute for Development Economics Research. 2000 Income distribution and tax, and government social spending policies in developing countries, Helsinki: World Institute for Development Economics Research of the United Nations University.

Cornia, G. A. 2004 Inequality, growth, and poverty in an era of liberalization and globalization, Oxford: Oxford University Press.

Dordunoo, C. K. and Nyanteng, V. K. 1997 'Overview of Ghanaian Economic Development', in V. K. Nyanteng (ed) Policies and Options for Ghanaian Economic Development, Accra: The Institute of Statistical, Social and Economic Research, University of Ghana.

Faaland, J., Parkinson, J. and Saniman, R. 2003 Growth and Ethnic Inequality Malaysia's New Economic Policy, Kuala Lumpur: Utusan Publications \& Distributors Sdn Bhd.

Figueroa, A., Altamariano, T., and Sulmont, D. 1996. Social Exclusion and Inequality in Peru. Geneva: International Labour Institute.

Ghai, D. and Court, D. 1974 Education, Society and Development: New Perspectives from Kenya, Nairobi: Oxford University Press.

Gurr, T. E. and Moore, W. H. 1997 'Ethnopolitical rebellion: a cross-sectional analysis of the 1980s with risk assessments for the 1990s', American Journal of Political Science 41(4): 1079-1103.

Gurr, T. R. 1970 Why men rebel, Princeton, N.J.: Published for the Center of International Studies, Princeton University [by] Princeton University Press.

- 1993 Minorities at Risk: A Global View of Ethnopolitical Conflicts, Washington DC: Institute of Peace Press.

Hall, G., Layton, H. M. and Shapiro, J. 2006 'Introduction: The Indigenous Peoples' Decade in Latin America', in G. Hall and H. A. Patrinos (eds) Indigenous Peoples, 
Poverty and Human Development in Latin America, Basingstoke: Palgrave Macmillan.

Hall, G. and Patrinos, H. A. (eds.) 2006 Indigenous Peoples, Poverty and Human Development in Latin America, Basingstoke: Palgrave Macmillan.

Herbst, J. 1993 The politics of reform in Ghana, 1982-1991, Berkeley: University of California Press.

Hutchful, E. 2002 Ghana's adjustment experience: The paradox of reform, Geneva and Oxford: UNRISD and James Currey.

IMF 1986 Fund-Supported Programs, Fiscal Policy and Income Distribution, Washington: International Monetary Fund..

Instituto Nacional de Estadística e Informática (INEI) 2002 'La pobreza en el Perú: Una visión departamental', June 2002, Lima, Peru.

- 2007 'Informe Técnico: Medición de la pobreza, 2004, 2005 y 2006', Lima, Peru.

Leite, S. P., Pellechio, A., Zanforlin, L., Begashaw, G., Fabrizio, S. and Harnack, J. 2000 'Ghana: Economic Development in a Democratic Environment', IMF Occasional Papers No. 1999, Washington: International Monetary Fund.

Mancini, L. 2005 'Horizontal inequalities and communal violence: evidence from Indonesian districts', CRISE Working Paper No. 22 Oxford: Centre for Research on Inequality, Human Security and Ethnicity, University of Oxford.

Mancini, L., Stewart, F. and Brown, G. 2008 'Approaches to the Measurement of Horizontal Inequalities', in F. Stewart (ed) Horizontal Inequalities and Conflict: Understanding Group Violence in Multiethnic Societies, London: Palgrave.

Manuh, T. 1997 'Ghana: Women in the Public and Informal Sectors under the Economic Recovery Programme', in N. Visvanathan, L. Duggan, L. Nisonoff and N. Wiegersma (eds) The Women, Gender and Development Reader, London: Zed Books.

Mensah, J., Oppong-Koranteng, R. and Frempah-Yeboah, K. 2006

'Understanding Economic Reforms: the Case of Ghana', in J. Mensah (ed)

Understanding Economic Reforms in Africa: A Tale of Seven Nations Basingstoke:

Palgrave Macmillan.

Murshed, M. S. and Gates, S. 2005 'Spatial-horizontal inequality and the Maoist insurgency in Nepal', Review of Development Economics 9(1): 121-134.

Østby, G. 2006 'Horizontal inequalities, political environment and civil conflict: evidence from 55 developing countries', CRISE Working Paper No. 28, Oxford: Centre for Research on Inequality, Human Security and Ethnicity, University of Oxford.

Roe, A. and Schneider, H. 1992 Adjustment and equity in Ghana, Paris: Development Centre of the Organisation for Economic Co-Operation and Development (OECD).

Singh, A. 2000 'Global economic trends and social development', Occasional Paper No. 9, Geneva: United Nations Research Institute for Social Development.

- 2007 'Capital account liberalization, free long-term capital flows, financial crises and economic development', in A. Shaikh (ed) Globalization and the Myths of Free Trade, London: Routledge.

Songsore, J. 2003 Regional development in Ghana: The theory and the reality, Accra: Woeli Publishing Services.

Stewart, F. 1995 Adjustment and Poverty: Options and Choices, London: Routledge. Stewart, F. and Wang, M. 2003 'Do PRSPs empower poor countries and disempower the World Bank, or is it the other way round?' QEH Working Paper Series No. 108, Oxford: Queen Elizabeth House, University of Oxford.

- 2005 'Poverty reduction strategy papers within the human rights perspective', in P. Alston and M. Robinson (eds) Human Rights and Development, Oxford: Oxford University Press.

Stewart, F. 2001 'Horizontal Inequalities: a Neglected Dimension of Development' WIDER Annual Lectures 5, Helsinki: WIDER. 
Wood, A. and Ridao-Cano C. 1996 'Skills, Trade and International Inequality', IDS Working Paper 47, Sussex: IDS.

Ukiwo, U. 2005 'The study of ethnicity in Nigeria', Oxford Development Studies 33(1): 7-24.

Van de Walle, D., Nead, K. and World Bank. 1995 Public spending and the poor: theory and evidence, Baltimore, MD: Johns Hopkins University Press. 